\title{
UNDIAGNOSED AIDS IN PATIENTS WITH PROGRESSIVE DYSPNOEA: AN OCCUPATIONAL RISK FOR HEALTHCARE WORKERS IN CROATIA
}

\author{
Kornelija MIŠE ${ }^{1}$, Maja VUČKOVIĆ ${ }^{1}$, Anamarija JURČEV-SAVIČEVIĆ ${ }^{2}$, \\ Ivan GUDELJ ${ }^{1}$, Irena PERIĆ ${ }^{1}$, and Joško MIŠE ${ }^{3}$ \\ Clinical Department for Pulmonary Diseases, Split University Hospital', Teaching Public Health Institute of Split \\ and Dalmatia County ${ }^{2}$, Split, Medicine School on University of Zagreb ${ }^{3}$, Zagreb, Croatia
}

Received in September 2010

CrossChecked in October 2010

Accepted in February 2011

\begin{abstract}
Pulmonary diseases are well documented and diverse in many patients with HIV in clinical stages 3 and 4. It is not unusual that these patients, most of whom do not know that they are already HIV-infected, are first examined and hospitalised by respiratory medicine specialists. While HIV-infection is relatively simple to diagnose if accompanied by advanced clinical manifestations and is regularly checked in patients with increased risk, this is not the case in low-risk patients, particularly in countries with low-level HIV epidemic and therefore low index of suspicion. Regular examination involves a series of tests, often including bronchoscopy with transbronchal lung biopsy in order to identify an interstitial lung disease and/or progressive dyspnoea. It is not uncommon that patients provide false or incomplete information about their lifestyle, which can mislead the clinician. At this point, HIV-infection is usually not suspected and healthcare workers may not strictly be following the safety principles which are otherwise applied when HIV-infection is known or suspect, although universal precautions are routine practice. At this point, the risk of exposure is the highest and HIV-transmission to healthcare workers is the most likely to occur. The cases presented here indicate that patients with progressive dyspnoea, which is typical of interstitial lung diseases, should undergo HIV-testing as a part of good clinical practice, even in a country with low-level HIV epidemic.
\end{abstract}

KEY WORDS: bronchoscopy, chest X-ray, HIV-infection, HIV-testing

Pulmonary diseases are well documented and diverse in almost any patient with human immunodeficiency virus (HIV) infection at clinical stage 3 and 4 , and greatly contribute to their morbidity and mortality (1-5).

Infection with HIV is well-known to cause immunological changes in the lung. In addition to the loss of CD4+ T cells, a lymphocytic alveolitis with CD8+ T cells, activation of pulmonary macrophages, and increased production of cytokines can all be seen, leading to progressive impairment in both cell- mediated and humoral immunity (3). The most common HIV-related pulmonary diseases are active pulmonary tuberculosis (TB) (6-8), Pneumocystis jirovecii pneumonia (9-12), non-specific interstitial pneumonitis $(3,5)$, disseminated mycobacteriosis primarily due to Mycobacterium avium complex (2, 3), Kaposi's sarcoma with pulmonary involvement $(13,14)$, Cryptococcus neoformans infection (14-16), and Cytomegalovirus pneumonia $(3,4,17)$. HIVrelated lung diseases are also a prognostic factor for poor patient survival $(2,3,18)$. 
It is not unusual that patients who are not aware or known to be HIV-infected are first examined and hospitalised by respiratory medicine specialists. These healthcare workers (HCWs) are in the forefront of diagnostic and therapeutic procedures, assisting patients prior to diagnosis.

Croatia is considered to have a low-level HIV epidemic. In 2010, the Croatian National Institute of Public health reported that men who have sex with men bore the highest burden of HIV epidemic in Croatia $(48.5 \%)$ followed by heterosexuals with nonsteady partners at high risk of HIV infection (24.2\%), heterosexuals with steady HIV-infected partners $(11.9 \%)$, injecting drug users (7.7 \%), haemophiliacs $(1.8 \%)$, children of HIV-infected mothers (1.4\%), and recipients of infected blood derivatives $(0.4 \%)$ (19). According to the same source, for $4.2 \%$ of the infected persons the route of transmission was unknown. In Croatia, HIV/AIDS (acquired immunodeficiency syndrome) have been monitored since the first documented cases in 1985. Between 1985 and 2009, there were 792 cases of HIV infection, 301 of which progressed to AIDS. Of the 792 patients, 164 died. The annual AIDS incidence is less than 4 per 1 million inhabitants, with an average of 15 new cases every year over the last ten years (19).

Occupational exposure to bloodborne viruses is very common. Exposure of HCWs to HIV-infected blood, fluids and tissues involves documented risk of HIV-transmission. Even though hospital transmission is uncommon, it involves serious implications and deserves full public health attention (20). Measures against hospital infection from patients with unknown risk factors are not always strictly followed by HCWs, particularly in countries with low-level HIV epidemic such as Croatia.

This article brings our experience with patients with AIDS who arrived to Split University Hospital Lung Diseases Department from 1999-2008, mainly with progressive dyspnoea and unknown HIVinfection.

It is our hospital practice to ask all patients to sign a consent form for any diagnostic test or procedure found to be needed. Therefore, these patients were not informed that they needed HIV testing before the actual tests was done.

As soon as HIV-infection was confirmed, the patients were referred to the HIV/AIDS Department of the Zagreb University Hospital for Infectious Diseases.

\section{CASE REPORTS}

\section{Case one}

A 56-year-old patient, engineer, married, father of two, smoker, who did not drink arrived to the department with a two-month history of fever, sweat, non-productive cough accompanied by progressive dyspnoea, and weight loss. The first chest X-ray showed no pathological changes (Figure 1). Suspicion fell on pulmonary TB or a malignant process with infiltrative growth in the bronchial wall, which do not show on standard X-ray. For this reason, the patient underwent fiberbronchoscopy (FBSC), which found a mass of thick, sticky, purulent secretion in all bronchial tubes bilaterally. The patient refused to undergo transbronchial lung biopsy. The biogram of the bronchial aspirate was sterile and the microscopy for M. tuberculosis negative, as well as the subsequent Loweinstein media culture. In the following 10 days the patient's condition dramatically deteriorated, and he developed severe dyspnoea. Accidentally, the patient admitted to have travelled to Tanzania twice for business over the last 20 years. This raised suspicion of HIV infection, and the patient underwent HIV testing, which turned out positive. HIV explained progressive dyspnoea and weight loss. The clinical stage of infection was probably 4 . Only at that point did the patient confess that he had multiple contacts with sex workers in Africa. His wife was also HIVinfected, but had been symptom-free for many years.

\section{Case two}

A 32-year-old married male patient, a driver, father of one, presented with a two-month history of intermittent fever, progressive difficulty breathing, non-productive cough, and on a few occasions, haemoptysis. The patient was admitted with a diagnosis of suspected pulmonary TB. Chest X-ray showed a somewhat more pronounced lung interstitium, bilaterally basal, with a more homogeneous structure pericardially on the right side (Figure 2). Since macroscopic bronchoscopy was normal, a transbronchial lung biopsy was done in the lower right lobe. A second biopsy for the immunohistochemical analysis of the lung was suggested since the pathologist suspected vasculitis on the basis of histopathological changes of unknown aetiology in the blood vessels of the lung interstitium. While waiting for the histopathology results of the second FBSC, the patient 


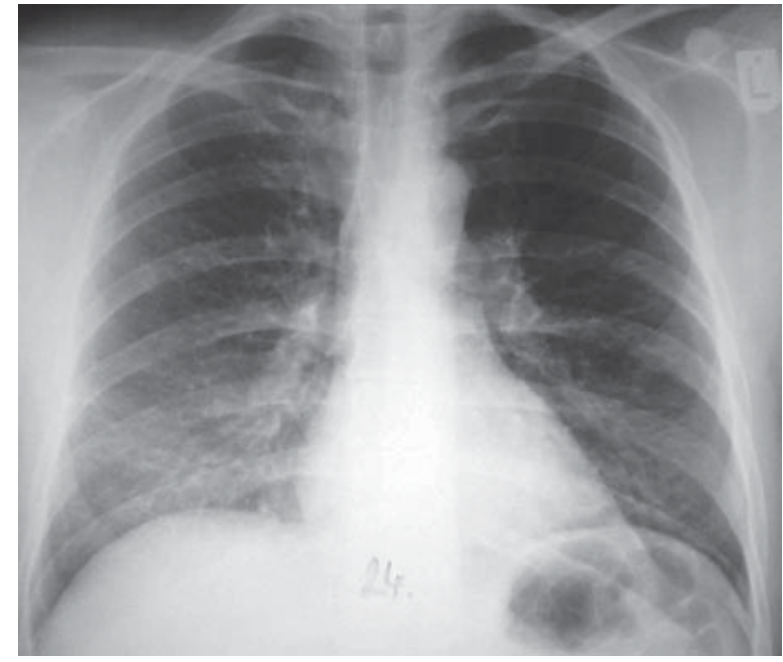

Figure 1 Case one chest X-ray: no pathological changes are visible in the lung parenchyma.

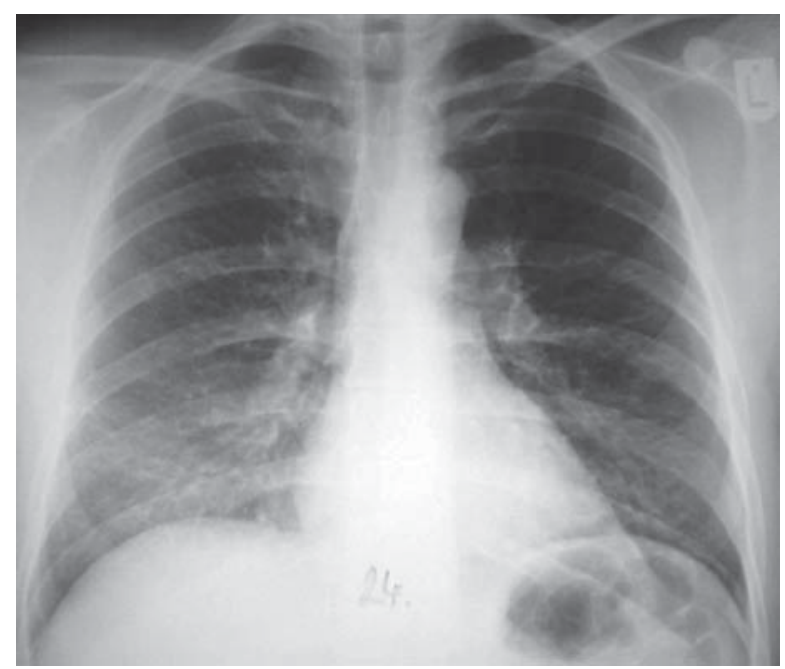

Figure 2 Case two chest X-ray: bilateral basal interstitial infiltration of the lung parenchyma, more pronounced pericardially on the right side. The rest of the finding is normal.

developed extreme breathlessness, aphthae and candidiasis in the oral cavity. At this point, he became suspect of HIV infection, and the HIV test turned out positive. Repeated transbronchial lung biopsy showed a dilated lung interstitium with thick fibrin deposits laden with Pneumocystis jirovecii (Figure 3). The infection was at clinical stage 4 . He admitted his highrisk heterosexual behaviour only after the diagnosis was made.

\section{Case three}

A 28-year-old married female patient, a housewife and a mother of two, who lived on an island, presented with a history of dyspnoea for several weeks,

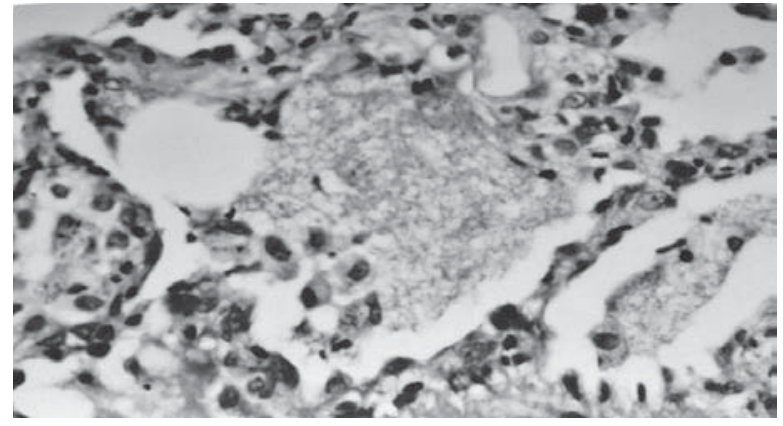

Figure 3 Case two histopathology of the lung sample taken by transbronchial lung biopsy. Dilated interalveolar septa infiltrated by thick deposits of $\mathrm{P}$. carinii.

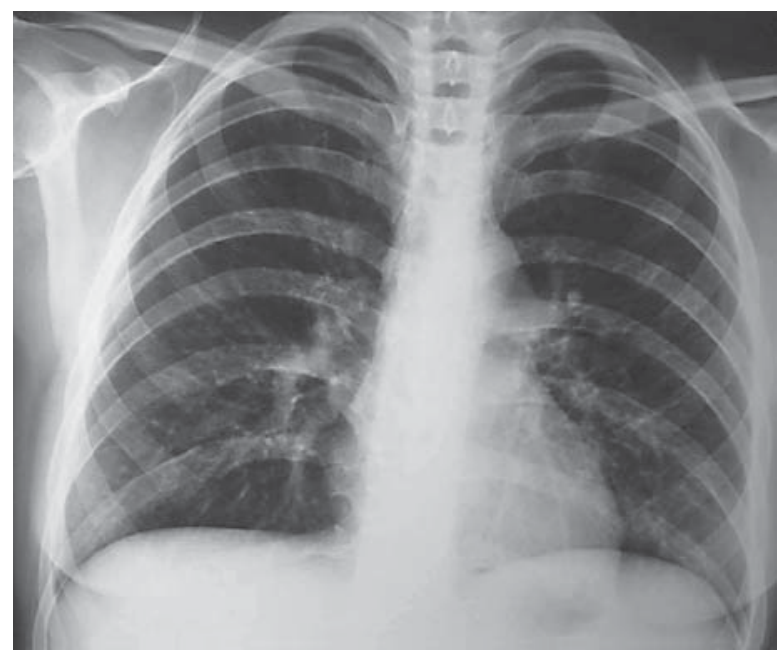

Figure 4 Case three chest X-ray image: no pathological changes are visible in the lung parenchyma.

intermittent fever with temperature up to $38^{\circ} \mathrm{C}$, and non-productive cough. Three days before hospital admission, she coughed up blood. The patient was examined in the outpatient unit; chest X-ray showed no pathological changes in the lung (Figure 4). Of her own initiative, the patient underwent computed tomography (CT) of the chest, which showed a slight diffuse infiltration in the lung interstitium, which is colloquially referred to as "frosted or ground glass" (Figure 5). Pneumocystis jirovecii pneumonia was suspected and HIV testing was positive. The infection was at clinical stage 4. Later it was found that she had multiple sexual partners.

\section{Case four}

A married, unemployed, female patient, mother of three, whose husband worked as a construction worker, was admitted to the hospital in a severe condition with widespread right-sided pneumonia (Figure 6). From haemoculture we isolated 


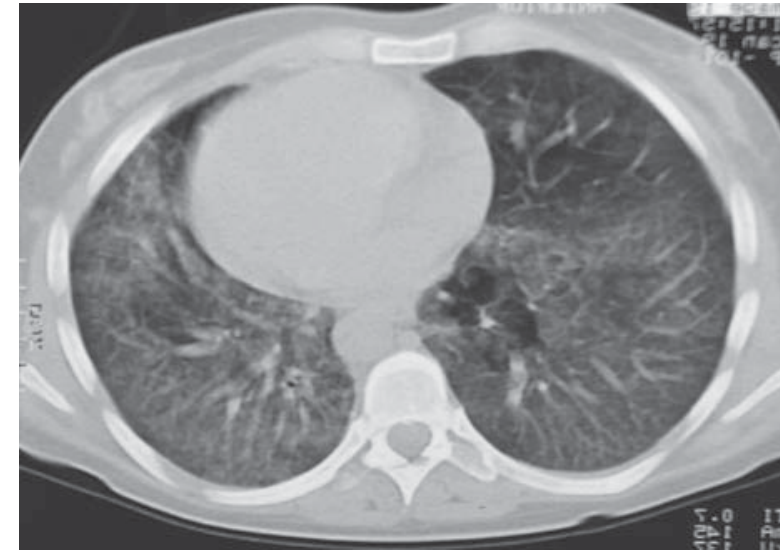

Figure 5 Case three chest CT scan: diffuse, bilateral thick infiltration of the lung interstice; so called "frosted glass"

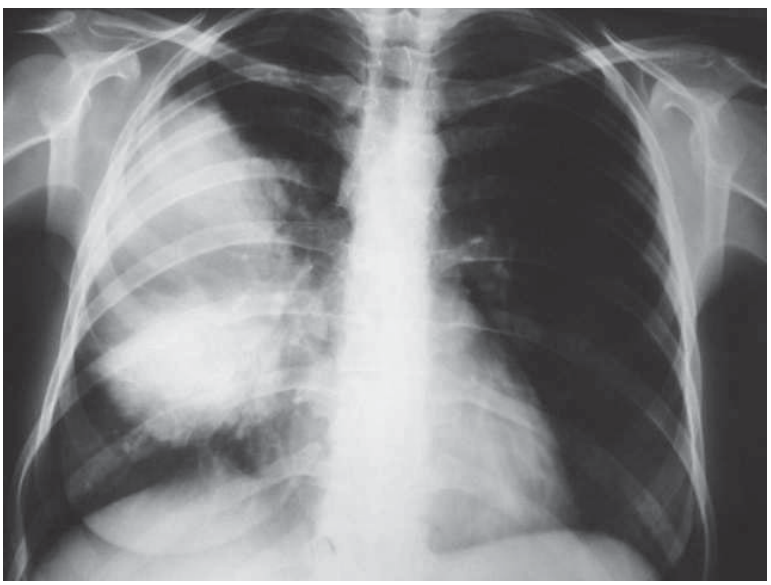

Figure 6 Case four chest X-ray: large and well-defined homogenous infiltration in the right lung

Streptoccocus pneumoniae and the patient was given antibiotics intravenously, according to the antibiogram. Despite therapy, the patient's clinical condition deteriorated; she remained febrile, developed severe dyspnoea, and expectorated pus mixed with blood. The X-ray showed progressive infiltrates with decay of the pulmonary parenchyma and cavity formation (Figure 7). FBSC was performed twice, since a concomitant infection with tuberculosis or a decayed malignant process were suspected. Multislice computed tomography (MSCT) showed decayed cavities of varying size in the right lung and "frosted glass" inflitrates in the lung interstitium. HIV testing, which was positive, was performed only after the patient developed stomatitis with aphthae. HIV infection was at stage 4. Her husband was HIVinfected, as well as two of her three children, the oldest and the youngest. It was later found that her husband had contacts with sex workers while he was working abroad.

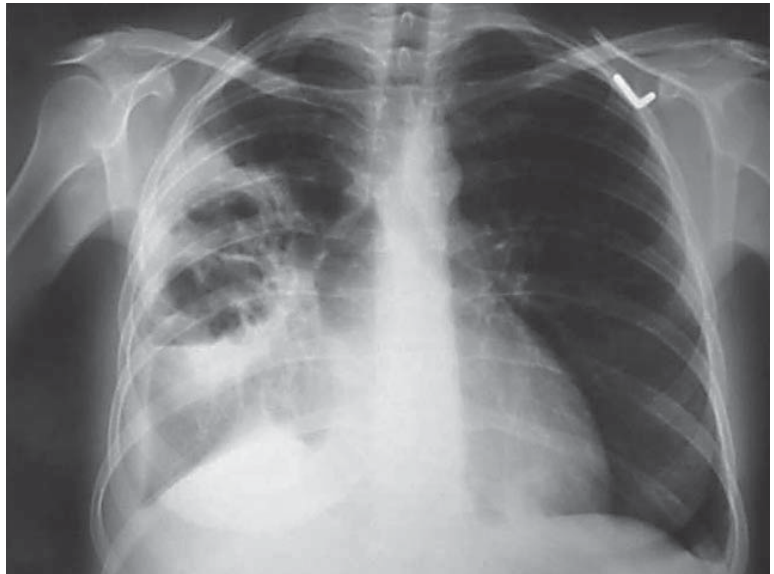

Figure 7 Case four second chest X-ray: progression of the infiltrate in the right lung with a number of larger caverns after seven days of antibiotic treatment

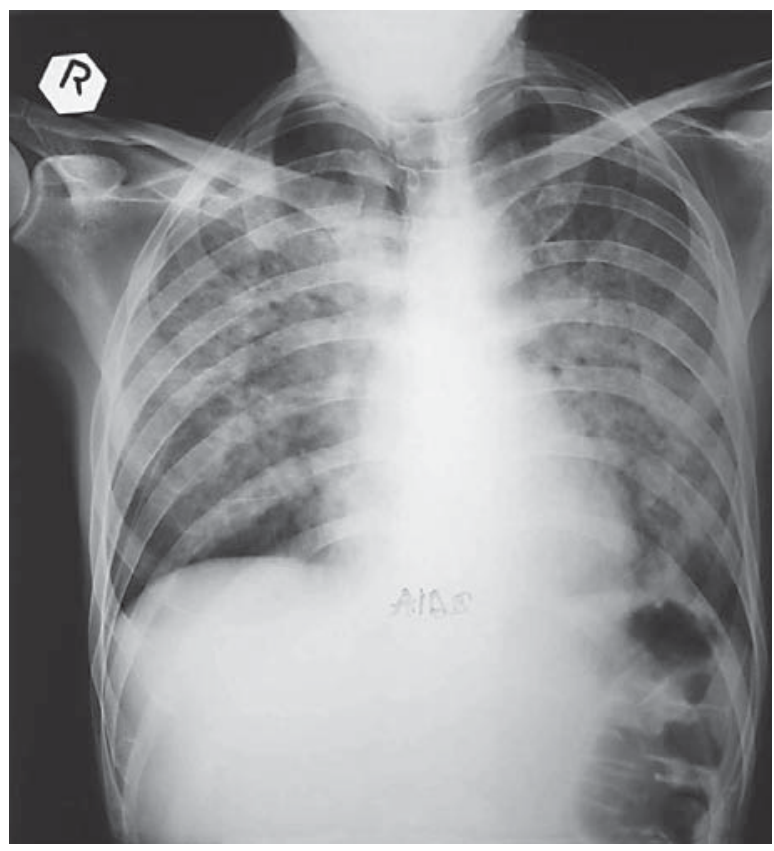

Figure 8 Case five chest X-ray image: multiple infiltration with large and small cavities in the pulmonary parenchyma

\section{Case five}

A 31-year old male patient, who was employed as a choreographer and travelling actor and had lived abroad, presented with extreme cachexia, fever, severe dyspnoea and pallor, but was conscious and responsive. Chest X-ray revealed multiple infiltration with larger and minor cavities in the pulmonary tissue (Figure 8), which raised suspicion of widespread caseocavernous pulmonary TB. Given the patient's difficult clinical condition and the information that he had lived abroad for many years in artistic circles and leading a specific lifestyle, the patient was tested for HIV, which proved 
positive. Only then did the patient admit that he had been suffering from AIDS. In the meantime, which turned out to be about five years, he was referred by his family doctor and medical staff from one health centre and laboratory to another, where he did a series of blood tests, all the time concealing his disease and wasting substantial amounts of time and medical resources and putting $\mathrm{HCWs}$ at risk. On admission, he suffered from the HIV wasting syndrome and 26 hours later he passed away. He was a high-risk heterosexual.

\section{DISCUSSION}

Many authors have reported dyspnoea and pulmonary manifestations in patients with HIV infection at clinical stage 3 and 4 (4-17). The disease may start with common respiratory difficulties, such as non-productive cough, haemoptysis, and dyspnoea.

All of our patients presented in this paper had AIDS at the time of admission to the hospital. Four were not aware of the disease, and one concealed it. Before HIV testing, we did not take a detailed history of sexual behaviour. Instead, our HCWs spent a few weeks in intensive examinations and treatment before diagnosing HIV infection or AIDS.

In the cases described above, no strict safety measures were applied by the medical staff when examining these patients. Since other symptoms, apart from haemoptysis, are neither typical nor specific, these patients usually underwent bronchoscopy. This is a test which can expose the bronchoscopy team to infectious agents through blood, particularly when transbronchial lung biopsy is taken, if standard precaution is not followed. Another threat is if a patient coughs up blood at staff performing bronchoscopy, particularly in local anaesthesia, as the distance between the person performing bronchoscopy and the patient is only $30 \mathrm{~cm}$ to $50 \mathrm{~cm}$. Another diagnostic procedure that can cause bleeding and put a $\mathrm{HCW}$ at risk is FBSC with lung biopsy. Two of our patients underwent FBSC twice and three once, totalling eight procedures that involve risk of HIV-infection. Taggart et al. (21) have noted that HIV-infected patients undergo between one and six bronchoscopies during follow-up. Of all their HIV-infected patients requiring bronchoscopy, $25 \%$ to $40 \%$ were new to the healthcare system. This issue has also been addressed by O'Neil who claims that there are many HIV-infected patients who are either unaware of or choose to ignore their infection, and who will present late in the course of their illness (2) According to the US Centers for Disease Control and Prevention (22), percutaneous injury (e.g., a needlestick or cut with a sharp object) or contact of the mucous membrane or nonintact skin with blood, tissue, or other body fluids that are potentially infectious might place HCWs at risk of HIV infection. Semen and vaginal secretions might be infectious, but have not been implicated in occupational transmission from patients to HCWs so far. The risk of HIV transmission from the cerebrospinal fluid, synovial fluid, pleural fluid, peritoneal fluid, pericardial fluid, and amniotic fluid is unknown, although these fluids considered potentially infectious. Some of the body excretions such as faeces, urine, sputum, nasal secretion, saliva, sweat, tears, and vomit are not considered potentially infectious, unless they are visibly bloody and it has been estimated that the risk of HIV transmission is low.

Bell (23) suggests that the average risk of HIV transmission through percutaneous exposure to infected blood is about $0.3 \%$ and through mucousmembrane exposure about $0.09 \%$, based on an Italian study (24). Despite some evidence (25), no estimation has been made so far as to HIV transmission through nonintact skin, but it is believed to be lower than from mucous-membrane exposure (25). The risk of transmission through exposure to fluids or tissues other than HIV-infected blood also has not been estimated so far, but it is probably lower than for blood exposures (27). In addition, the likelihood of transmission substantially depends on how infectious is the source and how susceptible the exposed (28).

It is therefore reasonable to assume that during bronchoscopy, HIV can be transmitted through the conjunctiva, unless the person performing it is wearing glasses or other protective eyewear. Yet, to our knowledge, there has been no evidence of HIV infection of HCWs performing bronchoscopy, including FBSC, which in Croatia is not used in patients with confirmed/ known HIV infection. However, exposure in a hospital setting and risk of infection are greater if patient's HIV status is unknown. We therefore recommend that all patients suffering from dyspnoea of undetermined aetiology, and not only those from high-risk groups, should immediately undergo HIV-testing. Moreover, HIV infection should be screened for even in the case of pleural and/ or pericardial effusion of undetermined aetiology $(31,32)$. 
Even though there is no argument that universal precautions can significantly reduce the risk of HIV infection $(33,34)$, they are not always followed to the letter (35), as in the cases presented here. All our staff that had performed bronchoscopy were tested for HIV infection twice in 12 months and were negative. Regardless, we strongly advise that our colleagues closely follow the universal precautions $(36,37)$. Effective incentives should help to address both organisational hurdles and individual attitudes to change behaviour in the desired direction (35).

To conclude, occupational risk of HIV infection can effectively be addressed if patients with progressive dyspnoea are automatically tested for HIV as part of good clinical practice, even in a country with low-level $\mathrm{HIV}$ epidemic, and if HCWs strictly follow universal precautions.

\section{REFERENCES}

1. World Health Organization (WHO). WHO case definitions of HIV for surveillance and revised clinical staging and immunological classification of HIV-related disease in adults and children. Geneva: WHO; 2007.

2. O'Neil KM. The changing landscape of HIV-related lung disease in the era of highly active antiretroviral therapy. Chest 2002;122:768-71.

3. Beck JM, Rosen MJ, Peavy HH. Pulmonary complications of HIV infection: report of the fourth NHLBI workshop. Am J Respir Crit Care Med 2001;164:2120-6.

4. Taylor IK, Coker RJ, Clarke J, Moss FM, Nieman R, Evans DJ, Veale D, Shaw RJ, Robinson DS, Mitchell DM. Pulmonary complications of HIV disease: 10 year retrospective evaluation of yields from bronchoalveolar lavage, 1983-93. Thorax 1995;50:1240-5.

5. Rosen MJ. Overview of pulmonary complications. Clin Chest Med 1996;17:621-31.

6. Getahun H, Gunneberg C, Granich R, Nunn P. HIV infectionassociated tuberculosis: the epidemiology and the response. Clin Infect Dis 2010;50(Suppl. 3):S201-7.

7. Mugusi FM, Mehta S, Villamor E, Urassa W, Saathoff E, Bosch RJ, Fawzi WW. Factors associated with mortality in HIV-infected and uninfected patients with pulmonary tuberculosis. BMC Public Health 2009;9:409.

8. Lazarus JV, Olsen M, Ditiu L, Matic S. Tuberculosis-HIV co-infection: policy and epidemiology in 25 countries in the WHO European region. HIV Med 2008;9:406-14.

9. Albino JA, Shapiro JM. Early bronchoscopic diagnosis of concomitant tuberculosis and Pneumocystis carinii pneumonia in patients with HIV infection. J Assoc Acad Minor Phys 1996;7:99-103.

10. van Heese AH, Risseeuw GA. Pneumocystis carinii pneumonia in a HIV-positive patient. JBR-BTR 2010;93:154-5.

11. Saldana MJ, Mones JM. Pulmonary pathology in AIDS: atypical Pneumocystis carinii infection and lymphoid interstitial pneumonia. Thorax 1994;49(Supplement): S46-55.
12. Golden JA, Hollander H, Stulbarg MS, Gamsu G. Bronchoalveolar lavage as the exclusive diagnostic modality for Pneumocystis carinii pneumonia. A prospective study among patients with acquired immunodeficiency syndrome. Chest 1986;90:18-22.

13. Rezza G, Andreoni M, Dorrucci M, Pezzotti P, Monini P, Zerboni R, Salassa B, Colangeli V, Sarmati L, Nicastri E, Barbanera M, Pristerà R, Aiuti F, Ortona L, Ensoli B. Human herpesvirus 8 seropositivity and risk of Kaposi's sarcoma and other acquired immunodeficiency syndrome-related diseases. J Natl Cancer Inst 1999;91:1468-74.

14. Mitsuyasu RT. AIDS-related Kaposi's sarcoma: current treatment options, future trends. Oncology (Williston Park) 2000;14:867-78.

15. Wallace JM, Hansen NI, Lavange L, Glassroth J, Browdy BL, Rosen MJ, Kvale PA, Mangura BT, Reichman LB, Hopewell PC. Respiratory disease trends in the pulmonary complications of HIV infection study cohort. Pulmonary complications of HIV infection study group. Am J Respir Crit Care Med 1997;155:72-80.

16. de Lalla F, Vaglia A, Franzetti M, Manfrin V, Pellizzer GP, Fabris P. Cryptococcal pleural effusion as first indicator of AIDS: a case report. Infection 1993;21:192.

17. Uberti-Foppa C, Lillo F, Terreni MR, Puglisi A, Guffanti M, Gianotti N, Lazzarin A. Cytomegalovirus pneumonia in AIDS patients: value of cytomegalovirus culture from BAL fluid and correlation with lung disease. Chest 1998;113:919-23.

18. Vlahov D, Graham N, Hoover D, Flynn C, Bartlett JG, Margolick JB, Lyles CM, Nelson KE, Smith D, Holmberg S, Farzadegan H. Prognostic indicators for AIDS and infectious disease death in HIV-infected injection drug users: plasma viral load and CD4 $4^{+}$cell count. JAMA 1998;279:35-40.

19. Nemeth Blažić T. Epidemiologija HIV infekcije i AIDS-a u Hrvatskoj [Epidemiology of HIV-infection and AIDS in Croatia, in Croatian]. [displayed 8 September 2010]. Available at: http://www.hzjz.hr/epidemiologija/hiv.htm.

20. Zenner D, Tomkins S, Charlett A, Wellings K, Ncube F. HIV prone occupational exposures: epidemiology and factors associated with initiation of post-exposure prophylaxis. J Epidemiol Community Health 2009;63:373-8.

21. Taggart S, Breen R, Goldsack N, Sabin C, Johnson M, Lipman $\mathrm{M}$. The changing pattern of bronchoscopy in an HIV-infected population. Chest 2002;122:878-85.

22. Centers for Disease Control and Prevention. Updated U.S. Public Health Service Guidelines for the Management of Occupational Exposures to HIV and Recommendations for Postexposure Prophylaxis. MMWR 2005 [displayed 8 September 2010]. Available at:http://aidsinfo.nih.gov/ contentfiles/HealthCareOccupExpoGL.pdf.

23. Bell DM. Occupational risk of human immunodeficiency virus infection in healthcare workers: an overview. Am J Med 1997;102(Suppl. 5B):9-15.

24. Ippolito G, Puro V, De Carli G; The Italian Study Group on Occupational Risk of HIV infection. The risk of occupational human immunodeficiency virus infection in health care workers. Italian Multicenter Study. Arch Intern Med 1993;153:1451-8.

25. Centers for Disease Control and Prevention. Recommendations for prevention of HIV transmission in health-care settings. MMWR 1987;36(Suppl. 2):S1-18.

26. Fahey BJ, Koziol DE, Banks SM, Henderson DK. Frequency of nonparenteral occupational exposures to blood and body 
fluids before and after universal precautions training. Am J Med 1991;90:145-53.

27. Henderson DK, Fahey BJ, Willy M, Schmitt JM, Carey K, Koziol DE, Lane HC, Fedio J, Saah AJ. Risk for occupational transmission of human immunodeficiency virus type 1 (HIV1) associated with clinical exposures. A prospective evaluation. Ann Intern Med 1990;113:740-6.

28. Benn P, Fisher M. HIV and postexposure prophylaxis. Clin Med 2008;8:319-22.

29. Lucas MF. [Radiological manifestations of AIDS in the thorax, in Portuguese]. Acta Med Port 1992;5:539-45.

30. Marchiori E, Müller NL, Soares Souza A Jr, Escuissato DL, Gasparetto EL, Franquet T. Pulmonary disease in patients with AIDS: high-resolution CT and pathologic findings. AJR Am J Roentgenol 2005;184:757-64.

31. Heidenreich PA, Eisenberg MJ, Kee LL, Somelofski CA, Hollander H, Schiller NB, Cheitlin MD. Pericardial effusion in AIDS. Incidence and survival. Circulation 1995;92: 3229-34.

32. Khwaja S, Rosenbaum DH, Paul MC, Bhojani RA, Estrera AS, Wait MA, DiMaio JM. Surgical treatment of thoracic empyema in HIV-infected patients: severity and treatment modality is associated with CD4 count status. Chest 2005;128:246-9.
33. Sridhar MR, Boopathi S, Lodha R, Kabra SK. Standard precautions and post exposure prophylaxis for preventing infections. Indian J Pediatr 2004;71:617-25.

34. Wong ES, Stotka JL, Chinchilli VM, Williams DS, Stuart CG, Markowitz SM. Are universal precautions effective in reducing the number of occupational exposures among health care workers? A prospective study of physicians on a medical service. JAMA 1991;265:1123-8.

35. Wu S, Li L, Wu Z, Cao H, Lin C, Yan Z, Jia M, Cui H. Universal precautions in the era of HIV/AIDS: perception of health service providers in Yunnan, China. AIDS Behav 2008;12:806-14.

36. Siegel JD, Rhinehart E, Jackson M, Chialrello L; Healthcare Infection Control Practice Advisory Committee. 2007 Guideline for Isolation Precautions: Preventing Transmission of Infectious Agents in Healthcare Settings [displayed 7 September 2010]. Available at http://www.cdc.gov/hicpac/ 2007IP/2007isolationPrecautions.html.

37. Rutala WA, Weber DJ; Healthcare Infection Control Practices Advisory Committee (HICPAC). Guideline for Disinfection and Sterilization in Healthcare Facilities 2008 [displayed 7 September 2010]. Available at http://www.cdc.gov/ncidod/ dhqp/pdf/guidelines/disinfection_nov_2008.pdf. 


\section{Sažetak}

\section{NEDIJAGNOSTICIRANI AIDS U BOLESNIKA S PROGRESIVNOM DISPNEJOM: PROFESIONALNI RIZIK ZA ZDRAVSTVENE DJELATNIKE U HRVATSKOJ}

Različiti oblici plućnih bolesti detaljno su opisani u mnogih pacijenata inficiranih HIV-om te značajno pridonose kliničkoj slici AIDS-a. Stoga takve pacijente, koji obično i ne znaju da su HIV-pozitivni, najčešće obrađuju i hospitaliziraju specijalisti za plućne bolesti. Posumnjati na AIDS i tu pretpostavku potvrditi nije problem kod pacijenata s razvijenim kliničkim manifestacijama AIDS-a, a ni u pacijenata s poznatim rizičnim čimbenicima. Teškoće u postavljanju prave dijagnoze nastaju obično u pacijenata u kojih rizični čimbenici nisu poznati ili ih pacijenti namjerno skrivaju, posebno u zemlji niske incidencije HIV-infekcije $\mathrm{u}$ kojoj se na AIDS ne pomišlja dovoljno u diferencijalnoj dijagnozi. Tijekom dijagnostičkog procesa pacijent prolazi niz testova i pretraga, koji često uključuje bronhoskopiju i transbronhalnu biopsiju pluća s ciljem identificiranja patologije plućnog intersticija i/ili progresivne dispneje. S obzirom na to da pacijenti često taje podatke o svojim navikama i životnom stilu, kliničar može biti zavaran glede pravog smjera u postavljanju dijagnoze. Upravo u tom razdoblju, dok se ne pomišlja na mogući AIDS, mjere opreza zbogh prijenosa infekcije, kojih se liječnik inače pridržava kad je takva dijagnoza poznata, nisu uvijek strogo poštivane, premda to mora biti dijelom uobičajene prakse. Stoga je u takvim okolnostima rizik od izloženosti i moguće HIV-transmisije na zdravstvene djelatnike velik. Ovdje prikazani slučajevi upućuju na potrebu da se pacijenti s progresivnom dispnejom, tipičnom za bolesti plućnog intersticija, testiraju na prisutnost HIV-a kao dio dobre kliničke prakse, čak i u zemlji niske razine HIV-infekcije.

KLJUČNE RIJEČI: bronhoskopija, HIV-infekcija, rentgenogram pluća, testiranje na HIV

\section{CORRESPONDING AUTHOR:}

Kornelija Miše, MD, PhD

Department for Pulmonary Diseases,

Split University Hospital

Spinčićeva 1, 21000 Split, Croatia

E-mail:kornelijamise@yahoo.com 